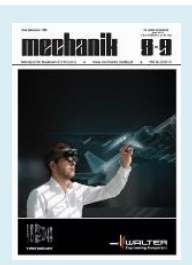

Authors: Adam Barylski, Maciej Gniot

Title of article: „Wpływ zawiesiny ściernej dawkowanej w sposób wymuszony na wydajność docierania jednotarczowego elementów ceramicznych" ("Effect of the abrasive slurry dispensed in a manner forced for the performance of single-disk lapping of ceramic elements")

\title{
Effect of the abrasive slurry dispensed in a manner forced for the performance of single-disk lapping of ceramic elements
}

\author{
Wpływ zawiesiny ściernej dawkowanej w sposób wymuszony \\ na wydajność docierania jednotarczowego elementów ceramicznych
}

\author{
ADAM BARYLSKI \\ MACIEJ GNIOT *
}

The article presents issues related to the preparation of an abrasive slurry in the running-in of flat machine surfaces. The research applied a forced method of dispensing a suspension of abrasive microspheres onto a cast iron ladder. The forcing system made it possible to control the amount of abrasive substance to be applied in a given time interval and to shape the size of the dispersion area dispensed to the work surface of the ladder.

KEYWORDS: lapping the flat surfaces, abrasive slurry, forced dosage

Lapping of flat surfaces is now one of the basic methods of very precise machining, carried out mainly in a machinelike manner, including on single-disk reach machines [1, 2, 8, 9]. Requirements for the elements of machines and tools force the use of devices that ensure high accuracy of machining. The quality of the lapping process is significantly influenced by, among others abrasive and the method of its dosing $[3,7]$. During lapping with the free-running teat, the slurry is usually supplied to the treatment zone continuously and with a large excess. Such dosing generates significant abrasive losses and increased tooling costs. For this reason, new dosing methods are sought that will solve this problem without compromising the quality of the surface lapping process itself.

In the conducted own research, machine oil L-AN 68ORLEN, cosmetic kerosene and microsphere silicon carbide 98C-F400/17 were used to prepare the abrasive slurry. The influence of the method of preparation of the abrasive slurry (share of individual components) and the intensity of dosing on the course and results of single-disk lapping of elements from $\mathrm{Al}_{2} \mathrm{O}_{3}$ ceramics were analyzed.

\section{Forced dosing system of the abrasive slurry}

The developed system of forced dosing of the abrasive slurry was created on the basis of the Abralap 380 single-disk dispenser, which is factory equipped with a continuous dosing system $[4,5]$. This generates increased abrasive wear - even at a level of approx. $400 \mathrm{ml} / \mathrm{min}$. The system of forced dispensing of slurry is shown in fig. 1.

\footnotetext{
* Prof. dr hab. inż. Adam Barylski (abarylsk@pg.edu.pl) - Wydział Mechaniczny Politechniki Gdańskiej; mgr inż. Maciej Gniot (maciej.gniot@ utp.edu.pl) - Wydział Inżynierii Mechanicznej Uniwersytetu Technologiczno-Przyrodniczego w Bydgoszczy
}

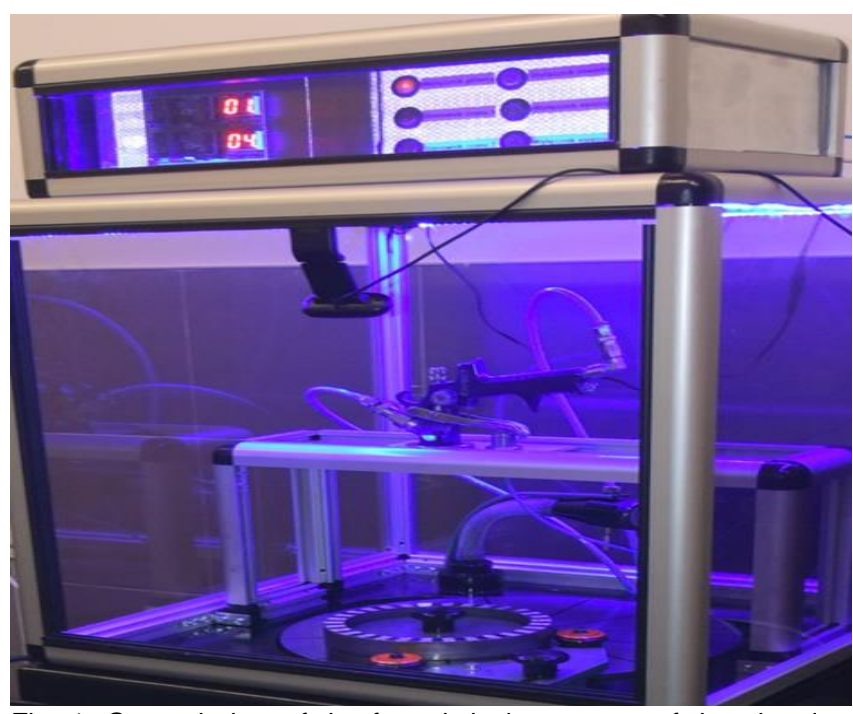

Fig. 1. General view of the forced dosing system of the abrasive slurry used in the Abralap 380 single disc peark machine

It allows dosing of the abrasive substance in a more rational manner, irrespective of the viscosity of the mixture of the treatment fluids used. Fig. 2 shows the surface of the driver, which has been coated with a suspension layer in a forced manner. It is easy to see that the applied layer evenly covers the entire working surface of the tumbler, creating a thin, uniform layer. Only at the edge of the guide ring (separators with objects) can you notice a slight overspug of the slurry, which is quickly removed during machining. The designed and built-up dosing system supplies the spray nozzle with an abrasive substance, and the direct control of the course of its application to the working surface of the driver is realized in the spire-nozzle socket system.

Fig. 3 shows a view of a sprayer-nozzle nest arrangement that is responsible for applying the abrasive substance periodically. A pneumatic actuator is connected to the sprayer needle. The electronic system [6] controls the whole dosing system. It ensures application of the required dose of abrasive substance in the machining zone. It is also possible to program the time intervals between successive sprays on the tool. The design of the spray nozzle corresponds to a specific dosage amount and the shape of the slurry spot. The nozzle allows application of a layer of abrasive slurry with the assumed thickness to the grinder. This application should be correlated with the rotational speed of the target disk. 


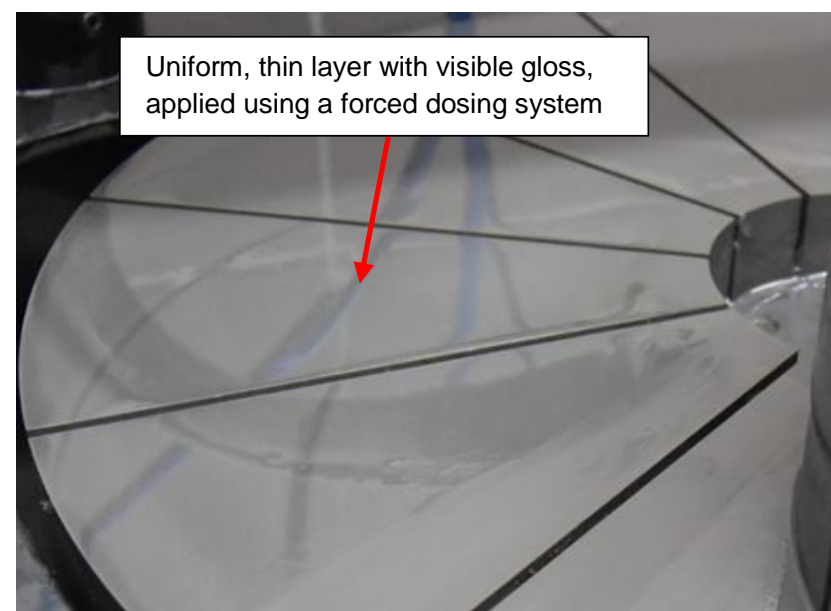

Fig. 2. Surface of the driver covered with abrasive substance

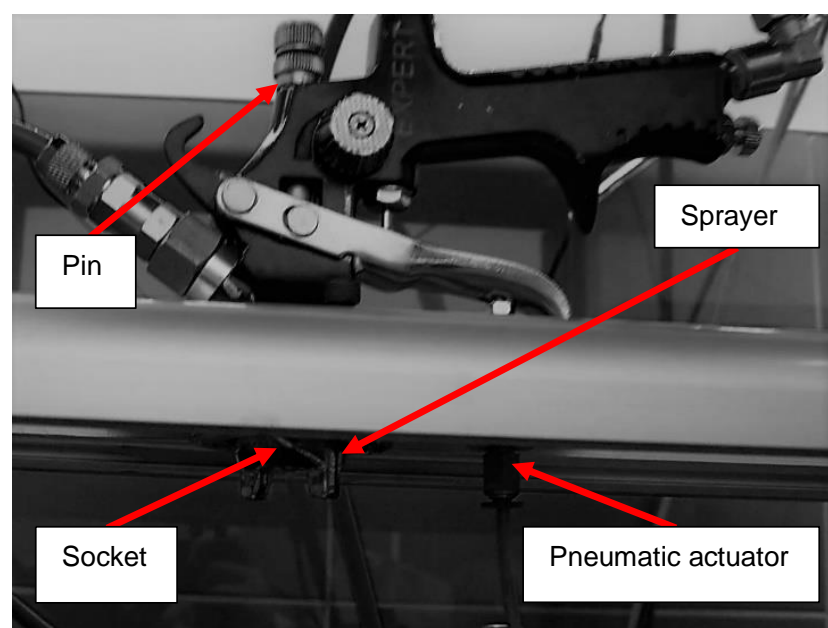

Fig. 3. General view of the spire-nozzle nest arrangement

\section{TABLE. Values of test factors in individual run-in tests}

\begin{tabular}{|c|c|c|c|}
\hline \multirow[b]{2}{*}{$\begin{array}{l}\text { Sample } \\
\text { number }\end{array}$} & \multicolumn{3}{|c|}{ Values of the factors studied } \\
\hline & $\begin{array}{l}\text { Content of abrasive } \\
\text { grains, by weight } K, \%\end{array}$ & $\begin{array}{l}\text { Ratio } \\
\text { of oil/kerosene } \\
\text { components }\end{array}$ & $\begin{array}{c}\text { Amount } \\
\text { of abrasive } \\
\text { substance } \\
V_{\mathrm{s}}, \mathrm{ml}\end{array}$ \\
\hline 1 & 9 & $18 / 10$ & 26 \\
\hline 2 & 21 & $18 / 10$ & 26 \\
\hline 3 & 9 & $18 / 10$ & 74 \\
\hline 4 & 21 & $18 / 10$ & 74 \\
\hline 5 & 9 & $42 / 10$ & 26 \\
\hline 6 & 21 & $42 / 10$ & 26 \\
\hline 7 & 9 & $42 / 10$ & 74 \\
\hline 8 & 21 & $42 / 10$ & 74 \\
\hline 9 & 5 & $30 / 10$ & 50 \\
\hline 10 & 25 & $30 / 10$ & 50 \\
\hline 11 & 15 & $30 / 10$ & 10 \\
\hline 12 & 15 & $30 / 10$ & 90 \\
\hline 13 & 15 & $50 / 10$ & 50 \\
\hline 14 & 15 & $30 / 10$ & 50 \\
\hline 15 & 15 & $30 / 10$ & 50 \\
\hline 15 & 15 & $30 / 10$ & 50 \\
\hline 17 & 15 & $30 / 10$ & 50 \\
\hline 18 & 15 & $30 / 10$ & 50 \\
\hline 19 & 15 & $30 / 10$ & 50 \\
\hline 20 & 15 & $30 / 10$ & 50 \\
\hline
\end{tabular}

For example, if the driver has a rotational speed of $60 \mathrm{rpm}$, then after one second, the surface of the disc will be completely covered with the prescribed dose of the abrasive substance.

In the conducted experiments, a statistical plan, determinate, selection, quasi-rotatabilty of the second order, with a spherical distribution of information was used [10]. The values of test factors in subsequent tests are included in the table.

Fig. 4 shows the calculated thickness of the abrasive layer that has been applied to the lapping mill during lapping. The examined factors were: the content of abrasive grains in suspension, the volume of abrasive substance and the ratio of liquid components (oil and kerosene), which were changed at five levels.

Fig. 5 and fig. 6 present the results of the research after statistical elaboration and the designated trend line. The tests were carried out at the average speed $v=0.68 \mathrm{~m} / \mathrm{s}$ and the unit pressure $p=0.0446 \mathrm{MPa}$. Analysis of the course of dependence of applied dose and content of abrasive grains on the loss of elements confirmed the advantages of forced dosing of the suspension.

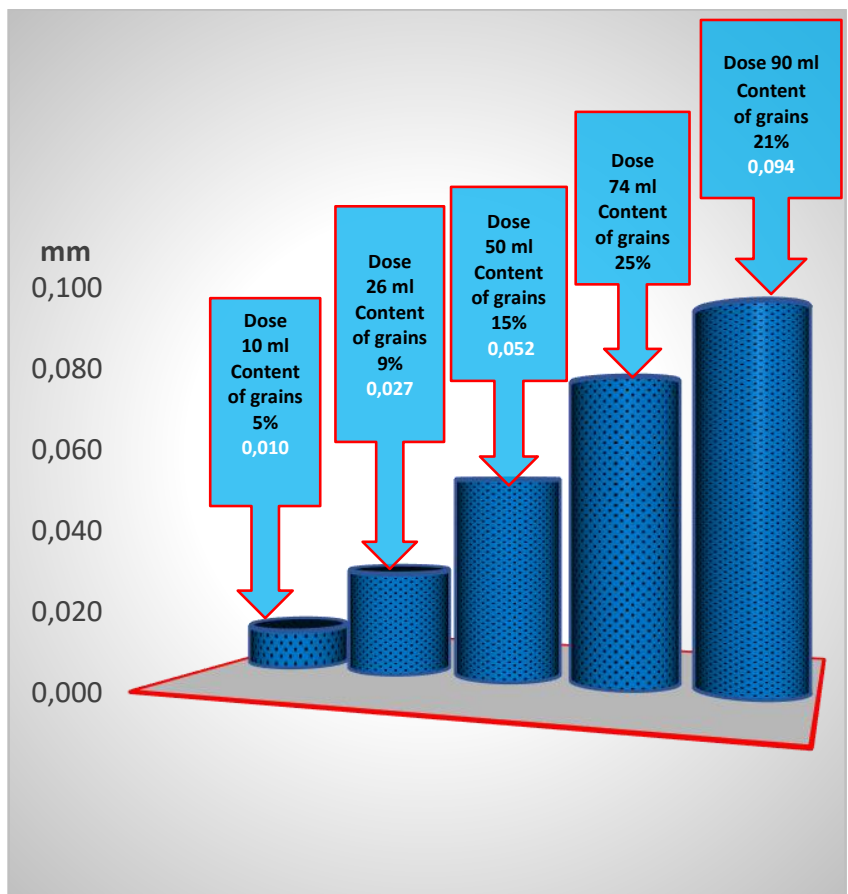

Fig. 4. Values of the thickness of the abrasive slurry layer (with different share of abrasive grains, expressed in \%) dosed on the runner within $20 \mathrm{~min}$

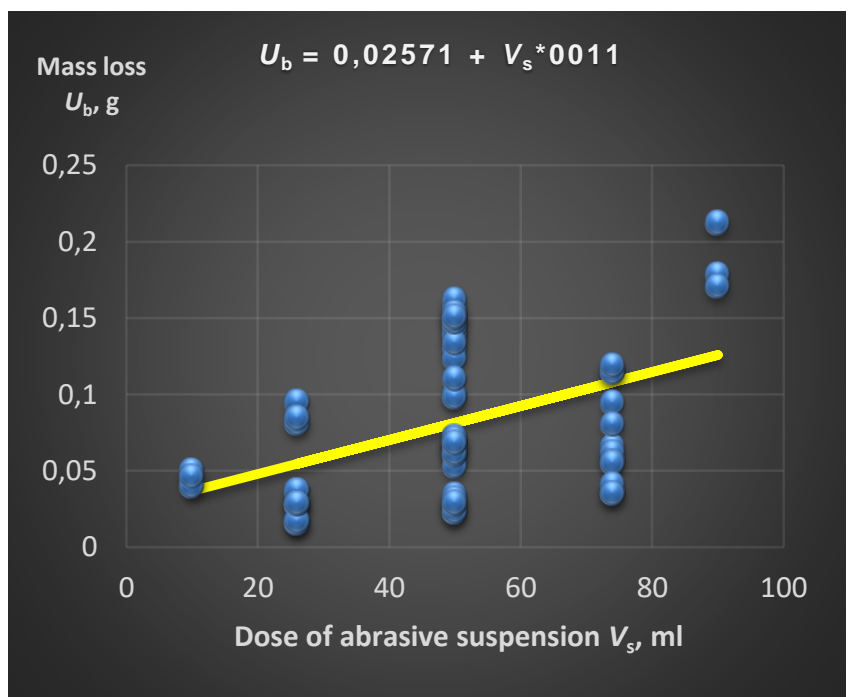

Fig. 5. Influence of the size of the $V_{\mathrm{s}}$ of the abrasive substance on the mass loss of $\mathrm{Al}_{2} \mathrm{O}_{3}$ ceramics during lapping in $20 \mathrm{~min}$ 


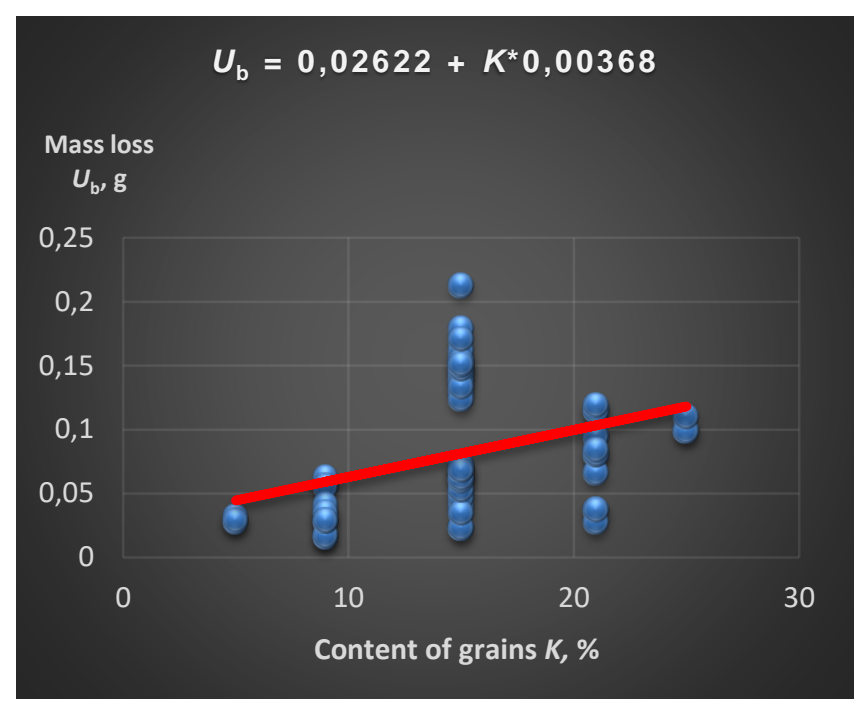

Fig. 6. Influence of abrasive grains content in the abrasive substance on the $U_{\mathrm{b}}$ cavity of $\mathrm{Al}_{2} \mathrm{O}_{3}$ ceramics during lapping (during $20 \mathrm{~min}$ )

These include relatively low consumption of the abrasive slurry while maintaining the efficiency of the process, expressed by the loss of weight of the work pieces during the assumed lapping time (20 $\mathrm{min})$.

\section{Conclusions}

The following advantages of this solution can be distinguished on the basis of the analysis of the impact of conditions of forced dosing of the abrasive slurry on the performance of the lapping process:

- consumption of the abrasive slurry is significantly lower compared to traditional dispensing methods;

- application of the slurry is more repeatable, and on the surface of the extruder a uniform thin layer of abrasive with a visible gloss is formed, which proves its uniform thickness;

- applied solution enables the application of a layer of suspension of a given thickness, and the total covering of the wheel can take place after one second;

- the use of a continuous slurry mixing system counteracts the sedimentation of the abrasive in the pressure vessel;

- developed system allows to control the time interval between consecutive doses applied to the center, which allows better planning of the dosing process;
- the system ensures dosing of the prescribed dose over a specified period of time, which has the effect of reducing the amount of abrasive slurry needed for lapping the elements.

To sum up: the presented solution allows for a significant reduction of processing costs, and indirectly also contributes to the improvement of environmental protection.

\section{REFERENCES}

1. Bakoń A., Barylski A. „Preparaty na bazie nano- i mikrodiamentów do operacji docierania i polerowania". Mechanik. 87, 8-9 (2014): pp. 8-12.

2. Bakoń A., Barylski A. „Ziarna i mikroziarna diamentowe. Rodzaje ścierniw i przykłady zastosowania”. Gdańsk: Wydawnictwo Politechniki Gdańskiej, 2017.

3. Barylski A. „Badania wpływu koncentracji ścierniwa i intensywności "dawkowania zawiesiny na efekty docierania jednotarczowego". Mechanik. 88, 8-9 (2015): pp. 20-24.

4. Barylski A. „Docieranie powierzchni płaskich na docierarkach”. Gdańsk: Wydawnictwo Politechniki Gdańskiej, 2013.

5. Barylski A. "Technological problems in lapping on flat surfaces of ceramic parts". Solid State Phenomena. 199 (2013): pp. 627-632.

6. Gniot M., Barylski A., Migawa K. „System dawkowania zawiesiny ściernej W docieraniu powierzchni płaskich". Mechanik 90, 10 (2017): pp. 894-896.

7. Gniot M., Barylski A. „Hydrodynamiczne dawkowanie zawiesiny ściernej w docieraniu jednotarczowym powierzchni płaskich”. Mechanik. 89, 8-9 (2016): pp. 1110-1111.

8. Marinescu I.D., Uhlmann E., Doi T.K. "Handbook of Lapping and Polishing. Manufacturing Engineering and Materials Processing". CRC Press, Taylor \& Francis Group, 2007.

9. Klocke F. "Manufacturing Processes 2 - Grinding, Honing, Lapping". Berlin-Heidelberg: Springer-Verlag, 2009.

10. Polański Z. "Metody optymalizacji w technologii maszyn”. Warszawa: PWN, 1977.

Translation of scientific articles, their computer composition and publishing them on the website www.mechanik.media.pl by original articles in Polish is a task financed from the funds of the Ministry of Science and Higher Education designated for dissemination of science.

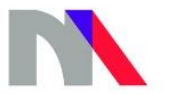

Ministry of Science and Higher Education Republic of Poland 